AGRICULTURE AND BIOLOGY JOURNAL OF NORTH AMERICA

ISSN Print: 2151-7517, ISSN Online: 2151-7525, doi:10.5251/abjna.2011.2.11.1395.1401

(C) 2011, ScienceHuß, http://www.scihub.org/ABJNA

\title{
Evaluation of Moringa oleifera, Gliricidia sepium and Leucaena leucocephala - based multinutrient blocks as feed supplements for sheep in South Western Nigeria
}

\author{
Adegun M.K, Aye P.A, Dairo F.A.S \\ Department of Animal Production and Health Sciences, Faculty of Agricultural Sciences, Ado- \\ Ekiti State University, Ado-Ekiti
}

\begin{abstract}
Moringa oleifera has not found much use as human food and feed for ruminants compared to other known fodder trees in South- Western Nigeria. Feed blocks were made using $30 \%$ Moringa oleifera, Gliricidia sepium and Leucaena leucocephala leaf meals to supplement basal diets of guinea grass - cassava peels mixture for small ruminants. The diets were fed to 32 West African Dwarf rams with average weight of $11.2 \pm 0.6 \mathrm{~kg}$ in a completely randomized design and body weight gain, linear body measurements, physiological parameters, nitrogen retention and

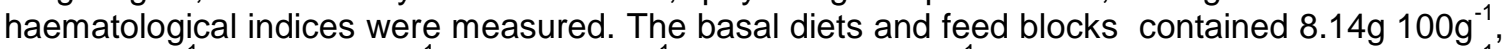

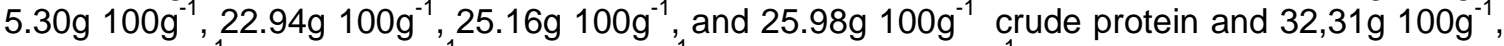

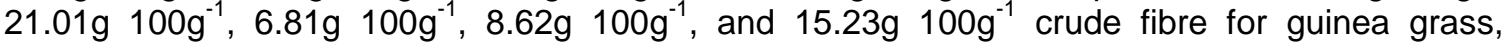
cassava peels, moringa- based multinutrient blocks (MMNB), gliciridia- based multinutrient blocks (GMNB), and leucaena- based multinutrient blocks (LMNB) respectively. The dry matter intake was 38.4, 40.6, 42.8 and 42.3 in control (Panicum + cassava peels), MMNB, GMNB, and LMNB, respectively indicating higher weight gains with supplemental feeding. Feed conversion ratio was 18.3, 11.6, 12.6 and 12.4 for control, MMNB, GMNB and LMNB, respectively. Body length, heart girth, height at withers, scrotal circumference and tail length gains were least in the control whereas GMNB had the highest body length and tail length gain. The nitrogen retention, of the animals on the supplemental MNBs were significantly $(\mathrm{P}<0.05)$ higher than the control group. White blood cell (WBC) and neutrophils values were 10.2, 8.3, 8.8 and $9.2 \times 10^{3} \mathrm{~mm}^{-1}$ and 27.5, 22.8, 23.7 and $22.8 \%$ for control, MMNB, GMNB, LMNB respectively. The values for other haematological parameters such as PCV, RBC, platelets, $\mathrm{Hb}, \mathrm{MCH}, \mathrm{MCHC}$ and MCV were significantly higher in the supplemental group than the control. Intake of multinutrient blocks do not pose any health hazard to the animals but enhanced better performance of sheep fed basal diets of Panicum maximum - cassava peels. Moringa oleifera compares favourably with Gliricidia sepium and Leucaena leucocephala as fodder tree for small ruminant holders in South Western Nigeria.
\end{abstract}

Keywords Moringa, Multinutrient, Conversion ratio,Retention,Heamatology

\section{INTRODUCTION}

The use of fodder trees and shrubs to solve the attendant problems of low productivity in small ruminant production has received research attention in recent times (Paterson et al., 1996; Makkar and Becker 1996; Aregheore, 2004). Some indigenous and a limited number of introduced species have been selected to serve as supplements to the low quality forage fed to these animals (Pezo et al., 1991). Most of the trials in the Humid Zone of West Africa (HZWA) conducted by the International Institute for Tropical Agriculture (IITA) and the International Livestock Centre for Africa (ILCA) involved Gliricidia sepium and Leucaena leucocephala which have shown benefits to crop production and animal improvement through alley farming and feed gardens. However, these species may have limitations in terms of productivity, palatability, presence of toxic substances and adaptability (Attah - Krah and Reynolds, 1989; Akinbamijo et al., 2006). Also, the reluctance of smallholder farmers to adopt these tree species as supplements for small ruminant nutrition has necessitated the search for other tree species which may offer additional benefits.

Moringa (Moringa oleifera Lamarck) is a slender, deciduous, perennial evergreen tree that originated in India but has spread to other regions of the world 
(Foidl et al., 2001). It is one of the fastest growing trees in the world with high biomass yield, high crude protein of $\pm 25 \%$ and a balance of other nutrients in the leaves (Makkar and Becker, 1996, Foidl et al, 2001; Asaolu et al, 2010). Moringa provides food, medicine, fuel and other uses but it's potential as an important browse plant for small ruminants diet supplementation has not been fully documented (Gutteridge and Shelton, 1993; Anjorin et al., 2010) Moringa can thrive well in any region where the soil is not waterlogged (Asaolu et al., 2006). Its cultivation as human food and livestock feed in the Southern states has not been popular because information on the feeding value is scarce (Asaolu et al., 2010).

One way of utilizing fodder trees is to use them as feed to small ruminants as part of, or along with, multinutrient blocks(MNBs) (Sansoucy, 1995; Agbede and Aletor, 2004; Aye, 2007). MNBs create an effective ecosystem and increase intake and digestibility of low quality, high fibre grasses usually consumed by the small ruminants(Habib et al.,1991). The production of MNBs ameliorate the loss of body condition often reported during the extended dry season (Aye, 2005). This study was designed to evaluate moringa, gliricidia and leucaena- based multinutrient blocks as feed supplements for West African Dwarf rams in South Western Nigeria.

\section{MATERIALS AND METHODS}

The experiment was carried out at the Teaching and Research Farm of the Ekiti State University Ado-Ekiti, Nigeria.Thirty-two (32) West African Dwarf (WAD) rams weighing $11.2 \pm 0.6 \mathrm{~kg}$ were purchased from Otun-Ekiti, Ekiti State, Nigeria and quarantined for 30days using the routine treatment developed at NAPRI(1984). The animals were housed in individual open sided, well- ventilated pens and allowed fourteen days adaptation period during which they were fed with multinutrient blocks, as well as Panicum maximum and cassava peels. The rams had free access to fresh water daily.

Multinutrient blocks of Moringa-molasses-urea, Gliricidia-molasses-urea and Leucaena-molassesurea were made. Cement was mixed $(\mathrm{w} / \mathrm{w})$ with water at ratio of 1:2, Moringa, Gliricidia, Leucaena leaf meals, molasses, urea, $\mathrm{NaCl}$ were added in that order and cement mixture added last. The mixture was poured into a cellophane-lined plastic mould. The feed blocks formed were put on table tops, sundried and packed into jute bags. The ingredient composition (\%) of feed blocks are as presented in Table 1.
Fresh guinea grass (Panicum maximum) was harvested and chopped into bits and allowed to wilt for 2-3 days and bailed into jute bags. Cassava peels were collected fresh from the Gari Processing Unit of the Teaching and Research Farm, sundried for five (5) days to moisture level of $10-13 \%$.

The animals were weighed before the commencement of the feeding regime and divided into four groups of eight animals balanced for body weight and randomly allocated to dietary treatments. The experimental diets were fed daily in two installments (morning and evening ). The feed blocks were fed to a basal diet of Panicum maximum plus cassava peels based on daily feed allowance of $5 \%$ of body weight. The animals were transferred into wooden metabolic cages fitted with facilities for collection of feaces and urines. The quantity of feed offered, feed refusal, feaces and urine were determined for 7 days, after 14 days of adjustment to cages. Ten percent of the feaces and urine collected daily over the 7-day period were bulked. Nitrogen loss from urine and bacteria growth infestation were prevented by introducing $20 \mathrm{~cm}^{3}$ of $10 \% \mathrm{H}_{2} \mathrm{SO}_{4}$ into urine collection bottles and refrigerated. Ten percent $(10 \%)$ of feaces were weighed and used for moisture determination and the remaining oven- dried at $70^{\circ} \mathrm{C}$ for 36 hours and milled.

Table1: Ingredient composition(\%) of the experimental multinutrient blocks.

\begin{tabular}{|l|l|l|l|}
\hline Ingredient & MMNB & GMNB & LUMNB \\
\hline & & & \\
\hline $\begin{array}{l}\text { Molasses } \\
\text { Moringa leaf meal }\end{array}$ & 30 & 40 & 40 \\
Gliricidia leaf meal & - & - & - \\
$\begin{array}{l}\text { Leucaena leaf meal } \\
\text { Urea }\end{array}$ & - & 30 & - \\
$\begin{array}{l}\text { Salt } \\
\text { Cement }\end{array}$ & 5 & - & 30 \\
\hline TOTAL & 10 & 5 & 10 \\
MMNB $=$ & 100 & 15 & 15 \\
GMNB $=$ & $\begin{array}{l}\text { Moringa Multinutrient block } \\
\text { LMNB }= \\
\text { Lliricidia Multinutrient block }\end{array}$ \\
\hline
\end{tabular}

The daily feed provided and left over of the previous day's feed were weighed to determine the total feed intake of each animal and on daily basis. Samples of experimental diets were collected for dry matter (DM) 
Agric. Biol. J. N. Am., 2011, 2(11): 1395-1401

determination and proximate analysis. The samples were weighed and oven- dried at $105^{\circ} \mathrm{C}$ 24hours, weighed and ground to pass through a $2 \mathrm{~mm}$ sieve. The animals were put into hessian bags and weighed weekly using a mobile hanging scale before the morning feed was offered. Body length, height at withers, heart girth, scrotal circumference and tail length were measured with tape rule. The respiratory rates were taken weekly with a stop watch, to time the flank movement per minute. The pulse rate was taken from the femoral artery for a minute (Kelly, 1980) while rectal temperature was taken with the digital clinical thermometer.

Blood was collected from the jugular veins of the animals at the start and at three-week intervals for analysis. The red blood cells (RBC), haemoglobin and other haematological indices such as erythrocyte sedimentation rate (ESR), lymphocytes, neutrophils, monocytes, eosinophils and basophils were determined and the mean corpuscular haemoglobin concentration (MCHC), mean corpuscular haemoglobin $(\mathrm{MCH})$ and mean corpuscular volume (MCV) were calculated from RBC, haemoglobin $(\mathrm{Hb})$ and packed cell volume (PCV) values as described by Benson et al. (1989) and Jain (1993). The white blood cells (WBC) counts were determined as described by Lamb (1981).

Chemical analysis: The milled experimental diets and feacal samples were analyzed for dry matter
(DM), crude protein (CP), crude fibre(CF), ether extract (EE) and nitrogen free extract(NFE) using the procedures described in AOAC(1995). Gross energy (GE) of feeds was determined with adiabatic bomb calorimeter. The nitrogen content of the urine was determined by the micro- Kjeldahl method (AOAC, 1995)

Statistical Analysis: The data collected were subjected to analysis of variance (ANOVA) using the general linear model (GLM) procedure of MINITAB (2000). Significant differences among means were separated using the Duncan's Multiple Range Test (DMRT).

\section{RESULTS AND DISCUSSION}

Table 2 shows that the multinutrient blocks contained $25.16 \mathrm{~g} 100 \mathrm{~g}^{-}{ }^{1}, 22.94 \mathrm{~g} 100 \mathrm{~g}^{-}{ }^{1}$ and $25.9 \mathrm{~g}$ $100 \mathrm{~g}^{-}{ }^{1}$ crude protein for GMNB, MMNB and LMNB, respectively which are higher than the values for

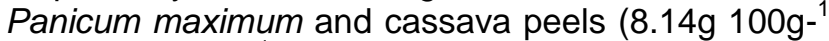
and $5.30 \mathrm{~g} 100 \mathrm{~g}^{-1}$ ).

LMNB had the highest crude fibre (15.23 $100 \mathrm{~g}^{-1}$ ) among the MNBs which is lower than those of

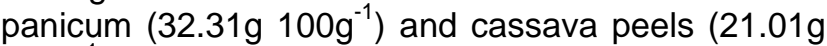
$\left.100 \mathrm{~g}^{-1}\right)$. Aye and Adegun (2010) noted that MNBs are lower in fibre but higher in crude protein than grasses and crop residues usually fed to small ruminants.

Table 2: Proximate compositions of the experimental diets $\left(\mathrm{g}^{100 \mathrm{~g}^{-1}}\right)$

\begin{tabular}{|l|l|l|l|l|l|l|l|}
\hline DIETS & DM & ASH & CP & CF & EE & NFE & MJ Kg $^{-1}$ \\
\hline & & & & & & & \\
\hline Panicum maximum & 84.35 & 13.26 & 8.14 & 32.31 & 3.52 & 42.78 & 22.03 \\
Cassava peels & 81.42 & 5.95 & 5.30 & 21.01 & 1.23 & 47.94 & 17.71 \\
GMNB & 92.83 & 6.72 & 25.16 & 8.62 & 12.39 & 39.95 & 16.17 \\
MMNB & 93.54 & 8.21 & 22.94 & 6.81 & 15.25 & 4.34 & 14.99 \\
LMNB & 92.14 & 8.08 & 25.98 & 15.23 & 11.88 & 30.98 & 17.50 \\
\hline
\end{tabular}

The performance characteristics of the experimental animals are presented in Table 3 . The average feed and dry matter intake were $15 \pm 0.03,16 \pm 0.03$, $17 \pm 0.5,1.8 \pm 0.02 \mathrm{~kg}$ and $38.4,40.6,42.3,42.8$ in control, MMNB,GMNB and LMNB, respectively. The higher intake values of MMNB,GMNB and LMNB agree with the results from Sansoucy and Aarts (1988) and Van Soest (1994) that supplementation increases consumption of basal diets. This is because of increased degradation of the basal diets and rate of passage of the digesta in the rumen due to increased activity of cellulolytic rumen microflora. The metabolic weight gains were $0.9_{ \pm} 0.02,1.4_{ \pm}$ $0.01,1.3 \pm 0.03$ and $1.3 \pm 0.04 \mathrm{~kg}$ for treatments $1,2, \overline{3}$ and 4 , respectively, the feed conversion ratio was highest in the treatment 3 (11.6), while treatments 2 and 4 were similar (12.4 and 12.6) and least in 
treatment 1 (18.3). The weight gain $(2.1 \pm 0.04)$ in treatment 1 was higher than negative value obtained when maize stover was fed to goats (Faftine and Zanetti, 2010) suggesting that guinea grass and cassava peels provided nutrients needed to maintain the animals. However, weight gains and feed conversion ratio in animals fed MNBs agree with the findings of Sansoucy, (1986); Aye and Adegun (2010) that supplements offer benefits to small ruminants.

Table 3: Performance characteristics of West African Dwarf (WAD) sheep fed multinutrient blocks(kg)

\begin{tabular}{|c|c|c|c|c|}
\hline PARAMETERS & CONTROL & MMNB & GMNB & LMNB \\
\hline Dry Matter Intake & $38.4^{c}$ & $40.6^{b}$ & $42.8^{\mathrm{a}}$ & $42.3^{\mathrm{a}}$ \\
\hline Feed Intake & $1.5 \pm 0.03^{b}$ & $1.6 \pm 0.0^{\mathrm{ab}}$ & $1.7 \pm 0.05^{\mathrm{ab}}$ & $1.8 \pm 0.02^{\mathrm{a}}$ \\
\hline Final Weight & $13.1 \pm 0.16^{b}$ & $14.6 \pm 0.22^{a}$ & $14.7 \pm 0.14^{\mathrm{a}}$ & $14.7 \pm 0.19^{a}$ \\
\hline Weight Gain & $2.1 \pm 0.04^{b}$ & $3.5 \pm 0.04^{\mathrm{a}}$ & $3.4 \pm 0.03^{a}$ & $3.4 \pm 0.02^{\mathrm{a}}$ \\
\hline Initial Metabolic Weight $\left\{w^{0.75} \mathrm{~kg}\right\}$ & $6.0 \pm 0.07^{\mathrm{C}}$ & $6.1 \pm 0.08^{b}$ & $6.2 \pm 0.06^{\mathrm{a}}$ & $6.2 \pm 0.07^{\mathrm{a}}$ \\
\hline Final Metabolic Weight $\left\{\mathrm{w}^{0.75} \mathrm{~kg}\right\}$ & $6.9 \pm 0.06^{b}$ & $7.5 \pm 0.09^{a}$ & $7.5 \pm 0.05^{\mathrm{a}}$ & $7.5 \pm 0.07^{\mathrm{a}}$ \\
\hline Metabolic Weight Gain $\left\{w^{0.75} \mathrm{~kg}\right\}$ & $0.9 \pm 0.02^{b}$ & $1.4 \pm 0.01^{a}$ & $1.3 \pm 0.03^{\mathrm{a}}$ & $1.3 \pm 0.03^{\mathrm{a}}$ \\
\hline Feed Conversion Ratio & $18.3^{\mathrm{a}}$ & $11.6^{\mathrm{C}}$ & $12.6^{b}$ & $12.6^{b}$ \\
\hline
\end{tabular}

$a, b, c$ means with different superscripts in the same row differs significantly $(p<0.05)$

Table 4 shows that GMNB had the highest body length gain of $12.5 \pm 0.59 \mathrm{~cm}$, followed by $11.3 \pm 0.45$ and $10.8 \mathrm{~cm}+0.44$ for LMNB and MMNB while control had $4 . \overline{5}+0.27 \mathrm{~cm}$. The heart girth gain, height at withers gain, scrotal circumference gain and

Table 4: Linear body measurements of West African Dwarf (WAD) sheep fed multinutrient blocks (cm)

\begin{tabular}{|l|l|l|l|l|}
\hline PARAMETERS & CONTROL & MMNB & GMNB & LMNB \\
\hline Initial Body Length & $69.8 \pm 0.91^{\mathrm{b}}$ & $69.5 \pm 1.32^{\mathrm{c}}$ & $69.5 \pm 1.50^{\mathrm{c}}$ & $70.3 \pm 0.36^{\mathrm{a}}$ \\
Final Body Length & $74.3 \pm 1.03^{\mathrm{C}}$ & $79.2 \pm 1.34^{\mathrm{b}}$ & $82.0 \pm 1.50^{\mathrm{a}}$ & $81.6 \pm 1.86^{\mathrm{a}}$ \\
Body Length Gain & $4.5 \pm 0.27^{\mathrm{d}}$ & $9.7 \pm 0.44^{\mathrm{C}}$ & $12.5 \pm 0.59^{\mathrm{a}}$ & $11.3 \pm 0.45^{\mathrm{b}}$ \\
Initial Heart Girth & $56.5 \pm 1.1^{\mathrm{b}}$ & $57.0 \pm 1.5^{\mathrm{a}}$ & $56.8 \pm 1.0^{\mathrm{b}}$ & $54.2 \pm 1.3^{\mathrm{C}}$ \\
Final Heart Girth & $61.3 \pm 0.77^{\mathrm{c}}$ & $65.5 \pm 0.85^{\mathrm{a}}$ & $65.6 \pm 1.2^{\mathrm{a}}$ & $62.8 \pm 1.4^{\mathrm{b}}$ \\
Heart Girth Gain & $4.8 \pm 0.42^{\mathrm{b}}$ & $8.5 \pm 1.20^{\mathrm{a}}$ & $8.8 \pm 0.75^{\mathrm{a}}$ & $8.6 \pm 0.54^{\mathrm{a}}$ \\
Initial Height at Withers & $50.5 \pm 0.5^{\mathrm{ab}}$ & $51.0 \pm 1.0^{\mathrm{a}}$ & $50.2 \pm 0.71^{\mathrm{b}}$ & $50.0 \pm 0.00^{\mathrm{b}}$ \\
Final Height at Withers & $58.6 \pm 0.5^{\mathrm{C}}$ & $65.5 \pm 1.4^{\mathrm{a}}$ & $64.0 \pm 0.59^{\mathrm{b}}$ & $63.8 \pm 1.3^{\mathrm{b}}$ \\
Height at Withers Gain & $8.1 \pm 0.20^{\mathrm{C}}$ & $14.5 \pm 0.90^{\mathrm{a}}$ & $14.6 \pm 0.63^{\mathrm{a}}$ & $13.8 \pm 0.63^{\mathrm{b}}$ \\
Initial Scrotal Circumference & $19.3 \pm 0.70^{\mathrm{a}}$ & $19.8 \pm 0.24^{\mathrm{a}}$ & $18.5 \pm 0.94^{\mathrm{b}}$ & $17.5 \pm 0.09^{\mathrm{C}}$ \\
Final Scrotal Circumference & $23.5 \pm 0.54^{\mathrm{C}}$ & $27.8 \pm 0.47^{\mathrm{a}}$ & $28.0 \pm 0.92^{\mathrm{a}}$ & $27.0 \pm 0.46^{\mathrm{b}}$ \\
Scrotal Circumference Gain & $4.2 \pm 0.37^{\mathrm{C}}$ & $8.0 \pm 0.29^{\mathrm{b}}$ & $9.5 \pm 0.36^{\mathrm{a}}$ & $9.5 \pm 0.36^{\mathrm{a}}$ \\
Initial Tail Length & $23.5 \pm 0.83^{\mathrm{b}}$ & $24.0 \pm 0.83^{\mathrm{a}}$ & $22.0 \pm 0.62^{\mathrm{c}}$ & $23.5 \pm 0.2^{\mathrm{b}}$ \\
Final Tail Length & $27.3 \pm 0.92^{\mathrm{c}}$ & $30.5 \pm 0.98^{\mathrm{a}}$ & $29.3 \pm 0.81^{\mathrm{b}}$ & $30.5 \pm 0.43^{\mathrm{a}}$ \\
Tail Length Gain & $3.8 \pm 0.18^{\mathrm{d}}$ & $6.5 \pm 0.26^{\mathrm{c}}$ & $7.3 \pm 0.27^{\mathrm{a}}$ & $7.0 \pm 0.16^{\mathrm{b}}$ \\
\hline
\end{tabular}

$a, b, c, d$ means with different superscripts in the same row differs significantly $(P<0.05)$ 
The physiological parameters of the experimental animals are shown in Table 5. Mean pulse rate of $77.53 \pm 0.12,76.56 \pm 0.22,76.59 \pm 0.14$ and $76.09 \pm$ 0.26 were recorded for treatments $1,2,3$ and 4 , respectively. The mean respiratory rate ranged from $25.4 \pm 0.11$, in animals fed supplemental GMNB to $28.4 \pm 1.10$ in animals fed control diet. The mean rectal temperature was $39.4,39.2,39.3$ and $39.3^{\circ} \mathrm{C}$.

The mean pulse rates were fairly constant and were not significantly different from each other $(P<0.05)$. The pulse rates fall within normal range reported as $70-90$ pulse/minute for sheep and goats (Kaushish, 2010). The rectal temperature was fairly constant and fell within the normal range for sheep $\left(32.6^{\circ} \mathrm{C}\right.$ to $39.6^{\circ} \mathrm{C}$ ) (Aye,2007). The respiratory rates were in no way negatively affected by the multinutrient blocks and this was in line with what was reported by Adams and MCKinley (1995)

Table 5: Physiological parameters of West African Dwarf (WAD) sheep fed multinutrient blocks

\begin{tabular}{lllll}
\hline PARAMETERS & CONTROL & MMNB & GMNB & LMNB \\
\hline Mean Pulse rate & $77.53 \pm 0.12^{\mathrm{a}}$ & $76.56 \pm 0.22^{\mathrm{b}}$ & $76.59 \pm 0.14^{\mathrm{b}}$ & $76.09_{ \pm} 0.26^{\mathrm{ab}}$ \\
Mean Respiratory rate & $28.4 \pm 1.10^{\mathrm{a}}$ & $26.6 \pm 0.18^{\mathrm{b}}$ & $25.4 \pm 0.11^{\mathrm{ab}}$ & $25.5 \pm 0.19^{\mathrm{ab}}$ \\
Mean Rectal Temperature & $39.4 \pm 0.01$ & $39.2 \pm 0.01$ & $39.3 \pm 0.03^{\mathrm{ab}}$ & $39.3 \pm 0.01^{\mathrm{ab}}$
\end{tabular}

$a b, c$ means with different superscripts in the same row differs significantly $\{p<0.05\}$

The result of nitrogen $(\mathrm{N})$ utilization is presented in Table 6. Mean metabolic live weight $\left(\mathrm{W}^{0.75} \mathrm{~kg}\right)$ of animals fed the MNBs $\left(7.5 \mathrm{~W}^{0.75} \mathrm{~kg}\right)$ was higher than the control group $\left(6.9 \mathrm{~W}^{0.75} \mathrm{~kg}\right)$.

$\mathrm{N}$ intake values ( $\mathrm{g} /$ day) obtained for sheep on MNBs ranged from $5.82 \pm 0.00-6.31 \pm 0.00$ compared to $2.15 \pm 0.00$ in the control. These values are within the range of $2.25-6.71 \mathrm{~g} /$ day reported by Kelly (1980) for sheep fed with supplements. The nitrogen digested and retained by sheep on MNBs were significantly $(P<0.05)$ higher than the control group and is in agreement with the results obtained by Hendratno et al. (1991); Aye and Adegun (2010). N retention increased with protein supplementation (Mupangwa et al., 2000) because MNBs made from tree fodder and urea enhanced the performance of small ruminants by providing a better balance of nutrients through improvement in rumen fermentation and supply of by- pass protein (Habib et al., 1991).

Table 6: Nitrogen Utilization of West African Dwarf (Wad) Sheep Fed Multinutrient Blocks

\begin{tabular}{|c|c|c|c|c|}
\hline PARAMETERS & CONTROL & MMNB & GMNB & LMNB \\
\hline Mean Live Weight (kg) & $13.1 \pm 0.16^{b}$ & $14.6 \pm 0.22^{\mathrm{a}}$ & $14.7 \pm 0.14^{\mathrm{a}}$ & $14.7 \pm 0.19^{a}$ \\
\hline Mean Live Weight $\left(\mathrm{W}^{0.75} \mathrm{Kg}\right)$ & $6.9 \pm 0.06^{b}$ & $7.5 \pm 0.09^{a}$ & $7.5 \pm 0.05^{\mathrm{a}}$ & $7.5 \pm 0.07^{\mathrm{a}}$ \\
\hline Nitrogen Intake (g/day) & $2.15 \pm 0.00^{c}$ & $5.82 \pm 0.00^{b}$ & $6.18 \pm 0.00^{a}$ & $6.31 \pm 0.00^{a}$ \\
\hline Feacal Nitrogen (g/day) & $1.92 \pm 0.02^{a}$ & $1.82 \pm 0.04^{b}$ & $1.81 \pm 0.03^{b}$ & $1.75 \pm 0.05^{\mathrm{c}}$ \\
\hline Digested Nitrogen (g/day) & $0.23 \pm 0.02^{b}$ & $4.00 \pm 0.04^{a}$ & $4.37 \pm 0.03^{a}$ & $4.47 \pm 0.02^{a}$ \\
\hline Urinary Nitrogen (g/day) & $0.85 \pm 0.02^{a}$ & $0.82 \pm 0.01^{a}$ & $0.65 \pm 0.02^{c}$ & $0.79 \pm 0.02^{b}$ \\
\hline Nitrogen Balance (g/day) & $1.04 \pm 0.03^{b}$ & $4.81 \pm 0.04^{a}$ & $5.02 \pm 0.05^{\mathrm{a}}$ & $5.35 \pm 0.05^{\mathrm{a}}$ \\
\hline Nitrogen Retention (g/day) & $40.52 \pm 2.42^{c}$ & $46.92 \pm 0.10^{b}$ & $52.34 \pm 0.20^{a}$ & $52.38 \pm 0.22^{a}$ \\
\hline
\end{tabular}

a,b,c means with different superscripts in the same row differs significantly $(p<0.05)$

The data presented in Table 7 show the blood profile of the experimental animals. The white blood cell (WBC) and neutrophils were significantly higher $(P<0.05)$ in control group than in animals fed the MNBs, but all the other haematological indices were significantly $(P<0.05)$ higher with supplemental diets. WBC obtained in animals fed MNBs are within normal range of $4.0-12.0 \times 10^{3} \mathrm{~mm}^{-1}$ for sheep (Byanet et al., 2008). The neutrophil counts fall within the normal physiological range of $10-50 \%$ for healthy sheep (Jain, 1993). The PCV, RBC, Platelets, and other calculated haematological values were within normal range for sheep (Dellmann and Brown 1987; Ikhimoya and Imasuen, 2007). The RBC counts in animals fed MNBs do not suggest a susceptibility to anaemia related disease condition because the values fall within the range of $9.2-13.5$ $\times 10^{12} / l$ reported by Tambuwal et al. (2002). It has 
been reported that haematological and biochemical indices give insight into the production potential and help to monitor and evaluate incidence of diseases in animals (Karesh and Cook, 1985; Orheruata and
Aikhuomobhogbe, 2000). The result of haematological parameters suggest that MNBs do not pose health challenges.

Table 7: Haematological indices of West African Dwarf (WAD) sheep fed multinutrient blocks

\begin{tabular}{|c|c|c|c|c|}
\hline PARAMETERS & CONTROL & MMNB & GMNB & LMNB \\
\hline White Blood Cells $\left(10^{3} \mathrm{~mm}^{-1}\right)$ WBC & $10.2^{\mathrm{a}}$ & $8.3^{b}$ & $8.8^{\mathrm{b}}$ & $9.2^{\mathrm{b}}$ \\
\hline Red Blood Cells (106mm-1)RBC & $9.8^{\mathrm{b}}$ & $9.6^{\mathrm{b}}$ & $10.8^{\mathrm{a}}$ & $10.6^{\mathrm{a}}$ \\
\hline Packed Cell Volume (\%) PVC & $27.7^{\mathrm{b}}$ & $31.7^{\mathrm{a}}$ & $33.6^{\mathrm{a}}$ & $32.6^{\mathrm{a}}$ \\
\hline Platelets & $10.97 \times 10^{4 b}$ & $11.67 \times 10^{4 a}$ & $11.50 \times 10^{4 a}$ & $11.40 \times 10^{4 a}$ \\
\hline Haemoglobin concentration $\left(\mathrm{gm} 100^{-1} \mathrm{~mm}\right) \mathrm{HbC}$ & $7.4^{\mathrm{b}}$ & $10.4^{\mathrm{a}}$ & $11.4^{\mathrm{a}}$ & $10.2^{\mathrm{a}}$ \\
\hline Erythrocyte sedimentation rate $\left(\mathrm{mmhr}^{-1}\right)$ ESR & $0.3^{\mathrm{c}}$ & $0.5^{\mathrm{b}}$ & $1.1^{\mathrm{a}}$ & $0.6^{\mathrm{b}}$ \\
\hline Mean Corpuscular Haemoglobin (pg) & $9.5^{\mathrm{b}}$ & $10.8^{\mathrm{a}}$ & $10.5^{\mathrm{a}}$ & $10.2^{\mathrm{a}}$ \\
\hline Mean Corpuscular Haemoglobin Conc.(\%) & $26.7^{c}$ & $72.8^{\mathrm{a}}$ & $33.9^{\mathrm{b}}$ & $31.3^{b}$ \\
\hline Mean Corpuscular Volume (m-3)MCV & $30.8^{\mathrm{b}}$ & $31.5^{\mathrm{a}}$ & $32.0^{\mathrm{a}}$ & $31.8^{\mathrm{a}}$ \\
\hline Neutrophils (\%) & $27.5^{\mathrm{c}}$ & $22.8^{\mathrm{b}}$ & $23.7^{\mathrm{a}}$ & $22.8^{b}$ \\
\hline Lymphocytes (\%) & $36.8^{\mathrm{b}}$ & $47.8^{\mathrm{a}}$ & $48.3^{a}$ & $46.3^{\mathrm{a}}$ \\
\hline Monocytes(\%) & $7.4^{\mathrm{b}}$ & $9.9^{\mathrm{a}}$ & $10.0^{\mathrm{a}}$ & $9.8^{\mathrm{a}}$ \\
\hline Eosinophils(\%) & $3.7^{\mathrm{c}}$ & $6.8^{\mathrm{b}}$ & $7.0^{\mathrm{b}}$ & $7.9^{a}$ \\
\hline Basophil (\%) & $0.4^{\mathrm{b}}$ & $1.0^{\mathrm{a}}$ & $1.0^{\mathrm{a}}$ & $1.0^{\mathrm{a}}$ \\
\hline
\end{tabular}

a,b,c means with different superscripts in the same row differs significantly $(p<0.05)$

\section{CONCLUSION}

The results of this study clearly show that supplementation of Moringa -based multinutrient blocks in small ruminants' diet can enhance better performance and pose no health challenges to the animals. Moringa oleifera compares favourably with Gliciridia sepium and Leucaena leucocephala nutritionally and can enhance the performance of sheep as protein supplements in south western Nigeria.

\section{REFERENCES}

Adams, D and McKinley, M(1995) The Sheep. ANZCCART News Vol 8 No 2 Pp 1-4

Agbede, J. O and Aletor V. A(2004) Chemical Characterization and protein quality evaluation of leaf protein concentrates from Gliricidia sepium and Leucaena leucocephala. J. Food Sci. Technol 39:253261.

Akinbamijo O.O. Adediran S.A, Nouala, S. and Seeker, J (2006) Moringa fodder in ruminant nutrition in the Gambia. Trees for life journal - a forum on beneficial trees and plants. Publication of International Trypanotolerance Centre, Banjul $\mathrm{T}$ retrieved on 6/4/2010 at HHP://www.tfjournal.org.

Anjorin T.S, Ikokoh, P. and Okolo, S (2010). Mineral composition of Moringa oleifera leaves, pods and seeds from two regions in Abuja, Nigeria . International Journal of Agriculture and Biology 12: pp $431-434$.
AOAC (1995) Official Methods of Analysis $16^{\text {th }}$ edition. Association of official Analytical Chemists, Arlington, Virginia, U.S.A

Aregbeore E.M (2004) Intake and digestibility of Moringa oleifera - batiki grass mixtures by growing goats small Ruminant Research 46(1) pp $23-28$.

Asaolu V.O, Odeyinka S.M, Akinbamijo O.O, Sodeinde F.G (2010) - Effects of Moringa and bamboo leaves on groundnut hayutilization by West African Dwarf goats. Livestock Research for Rural Development 22(1)

Attah-krah A.N and Reynolds L. (1989) Utilization of pasture and fodder shrubs in the nutrition of sheep and goats in the Humid tropics of West Africa - In FAO Animal Production and Health paper 70.

Aye, P. A (2005) Development of multinutrient blocks for the small ruminants in Nigeria. Proceedings $10^{\text {th }}$ Annual ASAN Conference Sept. 12-15 2005.Pp195196.

Aye, P. A.(2007)Production of multinutrient blocks for ruminants and alcohol from waste products of Leucaena and Gliricidia leaves using local technologies. Ph.D Thesis, Federal University of Technology Akure.

Aye P.A and Adegun M.K. (2010). Digestibility and growth in West African Dwarf (WAD) sheep fed gliciridia based multinutrient block supplements. Agricultural and Biology Journal of North America 1 (6): 1133 1139

Benson H.J, Gunstream S.E, Talaro A and Talaro KP(1989). Anatomy and physiology Laboratory Textbook wwmc Brown Publisher Dubuque 10WA. 
Byanet O, Adamu S, Salami, S.O and Onadiah, H.I (2008) Haematological and plasma biochemical parameters of the young grasscutter (Thyronomys swinderianus) reared in northern Nigeria Journal of cell and Animal Biology vol 2(10) pp177 - 181.

Dellman H, Brown E.M (1987). Blood andbone marrow. In textbook of Veterinary Histology, $3^{\text {rd }}$ Ed Lee Febiger, Philadelphia pp $71-86$.

Faftine O.L.J and Zanetti A.M (2010). Effect of multinutrient blocs on feed digestibility and performance of goats fed maize stover during the dry season in south Mozambique. Livestock Research for Rural Development 22(9)

Foidl N, Makkar H.P.S and Becker K. (2001). The potential of Moringa oleifera for agricultural and industrial uses. In: proceedings of International Workshop. What Development potential for Moringa Products October $29^{\text {th }}$ to November $2^{\text {nd }} 2001$. Darussalam, Tanzania.

Gutteridge R.C and Shelton H,M (1993) Forage tree Legumes in Tropical Agriculture published by the tropical grassland society of Australia Inc. pp 79-81.

Habib, W Basir A.S, Wahidullah W and Ghuftrnullah (1991). The importance of urea - molasses blocks and by-pass protein in Animal Production. The situation in Pakistan 135 - 145

Hendratno C, Nolan J.V. and Leng R.A (1991). The importance of Urea - molasses multinutrient blocks for ruminant production in Indonesia. International Atomic Energy Agency Vienna: pp 157 - 169.

Ikhimioya I and Imasuen J.A (2007). Blood profile of West African Dwarf Goats Fed Panicum maximum supplemented with Afzelia Africana and New bouldia laevis. Pakistan Journal of Nutrition 6(1): pp $79-84$.

Jain N.C (1993) essentials of veterinary Haematology Lea and Febiger Publishers Malvern, Pennysylvania U.S.A.

Karesh W.B, Cook R.A (1985). Application of veterinary medicine to in-situ conservation. Oryx 29:pp244 -252

Kaushish S.K (2010). A textbook of Animal husbandry kalyani Publishers, India.

Kelly W.R (1980) Veterinary clinical diagnosis $3^{\text {rd }}$ edition London. Builliere Tindall.

Lamb G.N (1981). Manual of Veterinary Laboratory. CIBA GEICY, Kenny. Pp $96-97$

Makkar, H.P.S and Becker K (1996) Nutritional value and anti nutritional components of whole and ethanol extracted Moringa olefera leaves. Animal Feed Science and technology. $63(1-4)$ pp $221-228$.

MINITAB (2000) Minitab Statistical software, Release 10.2. Minitab Inc., State college, P.A, USA.

Mupangwa J.F, Ngongoni, N.T, Topps, J.H, Hamudikuwanda $\mathrm{H}$ (2000). Effect of supplementing basal diet of Woris gayana hay with one of three protein rich legume hays of cassia rotunda, Lablab purpureus and macrophilium atropurpureus forage on some nutritional parameters in goats. Tropical journal of Animal Health and production 32 (4): Pp 245 - 256.

NAPRI(1984) Highlights of research achievements on animal production. Science and Technology briefing Lagos, December 1984 Pp3-17.

Orheruata A.M, Akhuomobhogbe P.U (2006). Haematological and blood biochemical indices of West African Dwarf (WAD) goats kaccinated againt pestes de peht ruminant (PPR). African Journal of Biotechnology 5: pp $743-748$.

Paterson R.T, Kiruiro E and Arimi H.K (1999) Calliandra colothyrsus as a supplement for milk production in the Kenya Highland. Tropical animal Health and Production, 31 pp $115-126$.

Pezo O, Cass $\mathrm{M}$, Benarides $\mathrm{J}$, romero $\mathrm{F}$ and chares $\mathrm{C}$ (1991) Potential of legume tree fodder as animal feed in central America. In shrubs and tree foddrs for farm animals. Devendra C (Ed) Idrec O Hawa, Ontario Canada. Pp163 - 1

Sansoucy R (1986) The sahel: Manufacture of Molasses Urea Blocks. World Animal Review 57:40-48.

Sansoucy $R$ (1995) New developments in the manufacture and utilization of multinutrient blocks.WAR/RMZ 82:7883.

Sansoucy R and Aarts G (1988). Molasses - urea blocks as multinutrient supplements for ruminants, Proc. F.A.O expert consultation on sugar cane as feed, Santo Domingo, Dominican Republic, July 1986, Rome, F.A.O.

Tambuwal F.M, Agala B.M, Bangana A. (2002). Haematological and biochemical values of apparently healthy red sokoto goats. In Proceedings of the $27^{\text {th }}$ annual conference of the Nigerian Society for Animal Production (NSAP), 17 - 21 March 2002, Federal University of Technology, Akure, Nigeria. Pp 50 - 53

Van Soest P.J (1994). Nutritional ecology of the ruminant $2^{\text {nd }}$ edition cornell Umv. Press, Lthaca, NY. 